\title{
Executive Poverty Experience and Corporate Social Responsibility Performance_-An Empirical Study Based on Shanghai and Shenzhen Listed Companies
}

\author{
Huaming Wang ${ }^{1, *}$, Bo Wang ${ }^{2}$ \\ ${ }^{1}$ Planning Finance Division, Southwest University of Science and Technology, Mianyang, PR China \\ ${ }^{2}$ School of Civil Engineering and Architecture, Southwest University of Science and Technology, Mianyang, PR China \\ Email address: \\ 393831787@qq.com (Huaming Wang),boy5240@163.com (Bo Wang) \\ ${ }^{*}$ Corresponding author
}

To cite this article:

Huaming Wang, Bo Wang. Executive Poverty Experience and Corporate Social Responsibility Performance_-An Empirical Study Based on Shanghai and Shenzhen Listed Companies. Journal of Finance and Accounting. Vol. 7, No. 2, 2019, pp. 49-55.

doi: $10.11648 /$ j.jfa. 20190702.13

Received: April 12, 2019; Accepted: May 20, 2019; Published: May 23, 2019

\begin{abstract}
In recent years, with the rapid development of China's economy, various environmental pollution, cottage food and consumer discrimination have caused frequent social responsibility problems, which have caused extremely bad effects on society and brought about the sustainable operation of China's economy. Case studies and theoretical studies have shown that the early experience of executives in the core leadership of the enterprise can have an impact on corporate decision-making. Taking 2012-2015 Shanghai and Shenzhen Listed companies as the research object, this paper studies the impact of executive poverty experience on the performance of corporate social responsibility. The results show that: executive poverty experience is positively correlated with performance of corporate social responsibility, the higher the poverty experience, the better corporate social responsibility is. Compared with state-owned enterprises, executive poverty experience has more influence on the performance of social responsibility of non-state-owned enterprises. This paper studies the motivation of corporate social responsibility from the new perspective, which is helpful to further grasp the influencing factors of corporate social responsibility and enrich the theoretical system of corporate social responsibility.
\end{abstract}

Keywords: Enterprise Executive, Poverty Experience, Corporate Social Responsibility

\section{Introduction}

Previous studies have attributed the main motivation of enterprises to the three aspects of economic development [1], institutional constraints [2] and external pressure [3]. Healy (1985) attributed the motivation of CSR to "egoism" and "altruism" from the perspective of economics [4]. From the existing research results, the relevant research on the motivation of corporate social performance is mainly based on the "egocentric" motivation, including the activities of corporate social responsibility that are beneficial to the economic development of enterprises, and are subject to institutional constraints and external pressure, which all belong to the category of "egocentric". Batson and Slingsby (1991) argued that only social responsibility activities derives from moral and emotional experience formed by personal experience can be regarded as truly "altruistic" activities [5]. As the most influential leader of an enterprise, the values and moral feelings formed by the personal experience of senior executives have an important impact on the formulation and implementation of corporate strategy and policy [6]. Therefore, will senior executives' poverty experience affect their corporate decision-making behavior and thus affect the fulfillment of corporate social responsibility? When studying the impact of poverty on individuals, Moon and Shen (2010) found that individuals who have experienced poverty are more likely to resonate with people who have suffered the same experience [7], put themselves in others' shoes and actively express their feelings of care and support. Hahn and Gawronski (2015) believe that the experience of poverty in the early stage can have a great impact on the individual's memory, thus affecting the formation of sympathy 
psychology and values in the early stage, and having a positive impact on the cultivation of professional ethics, emotion and social sympathy in the future [8]. Therefore, based on the viewpoints and inspirations of previous studies, this paper discusses and analyzes the relationship between executives' poverty experience and CSR fulfillment from the perspective of management and psychology, and may draw some new conclusions.

Based on this, this chapter will analyze the impact of senior management's early poverty experience on corporate social responsibility performance in 2012-2015, and examine the impact of senior executives' poverty experience on corporate social responsibility performance under different property rights. difference. The possible contributions of this chapter are as follows: (1) The early experience of executives plays an important role in the formation of executive personality and behavior patterns, and thus affects the decision-making of executives. This chapter will empirically study the early poverty experiences of senior executives in corporate society. The impact of responsibility fulfillment will help the theoretical community to further clarify the "altruistic" factors affecting the fulfillment of corporate social responsibility; (2) previous studies attribute the main motivations of enterprises to fulfill social responsibility to economic development, institutional constraints and external pressures. To test the impact mechanism of the poverty experience experienced by senior executives on the fulfillment of corporate social responsibility to verify the "altruistic" social responsibility activities of enterprises; (3) The measurement of the early poverty experience of executives is a new attempt. In order to provide ideas for future research.

\section{Theoretical Analysis and Research Hypotheses}

\subsection{Poverty Experience and Corporate Social Responsibility}

Regarding the impact of poverty experience on individual social responsibility behavior, according to the famous Dutch psychologist Hofstede, people who have experienced poverty are more likely to reflect the ideology of helping others. Poverty can cause memory shock to individuals and then to individuals. The way of thinking and the impact on the values of society. Holman and Silver (1998) believe that traumatic experience can often have an impact on individual behavior over a long period of time, while poverty experience, as the trauma to individual mind, can have an impact on the evaluation of future career value [9]. Malmendier et al. (2011) argue that, compared with other experiences, the experience of poverty has a more lasting impact on the individual's mind and behavior, and the experience of poverty has a more profound impact on the cultivation of individual values and sympathy [10]. People who have experienced poverty are more likely to be touched by their inner moral emotions, they are more able to put themselves in their shoes and express their feelings of care and support. Therefore, it can be inferred from the existing studies that individuals who have experienced poverty are more aware and motivated to fulfill their social responsibilities based on their true inner feelings.

Hambrick and Mason (1984) in the upper echelons theory, pointed out that corporate executives in the practical work is not "completely rational man" assumption of economics [11], corporate executive management decision-making process is often affected by cognitive skills, values and moral emotion, and the executive's personal experience to a certain extent, affect individual cognitive level, values and moral emotion. Behavioral finance believes that the management style and value judgment of senior executives are greatly influenced by the personality characteristics of senior executives, and senior executives are usually emotional [12-13]. Senior executives' management style can be reflected in the enterprise management and decision-making behavior, and their life experience and professional experience will affect the enterprise management policy. the poverty experience of senior executives can often bring greater memory impact to senior executives, so that they can better understand the significance of fulfilling social responsibilities [14-15]. Xu and $\mathrm{Li}$ (2016) also found in his research on poverty experience and senior executives' corporate behaviors that senior executives who had poverty experience in their childhood showed higher "consciousness of saving and helping" in their career process [16], and they were more able to treat subordinates and help others with empathy in work. Based on these studies, this paper proposes hypothesis 1:

H1: Senior executives with poverty experience have higher CSR performance level.

\subsection{The Impact of Different Property Rights on Corporate Social Responsibility Performance}

In the context of China's current transition economy, the growth environment and career development trajectory of senior executives of state-owned enterprises and non-state-owned enterprises are quite different [16-17], which also leads to great differences in the management styles and characteristics of senior executives of state-owned enterprises and non-state-owned enterprises. The executives of state-owned enterprises in childhood family often with soe background or relatively well-off family environment, whether it's "great famine" period or sudden natural disasters affect their families are relatively small, and for non-state-owned enterprise executives [18-19], childhood relatively no family or political background, advantages, for their early experiences, both living conditions and the career development path is more difficult, it is the hard experiences of early train their courage and saving consciousness, also more profound, the support of other people's thinking when become executive experience of poverty and suffering for others can empathy, And reach out to help. Based on these studies, this paper proposes hypothesis 2:

$\mathrm{H} 2$ : Compared with state-owned enterprises, senior executives' poverty experience has a stronger influence on 
non-state-owned enterprises to fulfill their social responsibilities.

\section{Sample Selection and Study Design}

\subsection{Sample Selection and Data Sources}

In this paper, the listed companies in Shanghai and shenzhen from 2012 to 2015 were taken as the research samples, and the samples were screened as follows:(1) financial and insurance companies were excluded; (2) excluding ST and *ST companies; (3) eliminate the samples with missing values and relevant financial data anomalies in each control variable. Finally, a total of 1796 observations of valid samples were obtained.

The data sources of this paper are mainly obtained from three ways:(1) the CSR performance index data comes from the score of runling global CSR evaluation system; (2) data of senior executives' poverty experience are obtained from the official websites of relevant enterprises, the website of the poverty alleviation office of the state council, the national bureau of statistics, baidu encyclopedia, interviews and reminiscences of celebrities, etc.; (3) financial data of listed companies are from CSMAR database, WIND database and sina financial website. The statistical software used in this paper is SPSS 22.0.

\subsection{Study the Definition of Variables}

\subsubsection{Corporate Social Responsibility (CSR)}

In this paper, the total score of corporate social responsibility rating of runling global from 2012 to 2015 is used as an alternative index to measure the CSR performance level of listed companies. The evaluation data of runling global responsibility rating company on the social responsibility performance of listed companies are derived from the annual reports and social responsibility reports issued by relevant enterprises. The evaluation system has strong objectivity, large amount of information and high accuracy, and has been used by many scholars to measure the social responsibility performance level of listed companies. The higher the total score of CSR rating, the higher the CSR performance level of listed companies. At the same time, when the robustness test is carried out in this paper, the proportion of charitable donations to the total assets of the enterprise (DON) is used for the robustness test.

\subsubsection{Poverty Experience (POV)}

There are few studies on the measurement methods of poverty experience in existing literatures. This paper referred to the measurement methods of $\mathrm{xu}$ and li (2016) and made improvements [16]. The following three types of indicators were selected to constitute the total alternative indicators of poverty experience of senior executives: First, the characteristics of executive early form depends on the development of the home environment, regional common economic activities, collective memory and mental characteristics of executives has great effect on early personality formation, therefore, consider executives early poor environment, to selected the poverty alleviation office of the state council in 2012 as "national poverty county" as an alternative indicators, compare the birthplace of executives and poverty-stricken list, to be included in the "national poverty county" assignment for 1 minute, otherwise the assignment 0; Rows and lil 'g second, reference years (2016) of the measurement method, considering from 1959 to 1961, three years of natural disasters in our country the effects on the poor more deeply, this article will executives whether early age experience our country "three years of hard times" as an alternative indicator, at the same time, according to the psychology for childhood age memory ability, defines the childhood age is 4 years old to 14 years old, therefore, will be born in 1947-1957 executive assignment for 1 minute, or assignment is 0 points; (3) experience of special poverty. For example, sudden natural disasters, family accidents, serious diseases and poverty caused by other sudden factors will also bring pains and hardships to the early experience of senior executives. Therefore, the value of having special poverty experience in the childhood of senior executives is 1 , or 0 . The total score of the above three indicators is added to form an alternative index for the senior executives' early poverty experience. The larger the index value is, the more senior executives' poverty experience will be. The statistics of executive poverty experience are shown in table 1.

Table 1. statistics of executive poverty experience.

\begin{tabular}{llll}
\hline Indicators & Poverty environment experience & Three years of hardship & Experience of special poverty \\
\hline Number & 136 & 659 & 87 \\
Sample size & 1796 & 1796 & 1796 \\
Proportion & $7.29 \%$ & $36.70 \%$ & $4.84 \%$ \\
\hline
\end{tabular}

Data sources: official websites of relevant enterprises, website of poverty alleviation office of the state council, baidu encyclopedia, celebrity biographies and interviews, etc.

\subsubsection{Control Variables}

Also consider the impact on corporate social responsibility may be related factors, this paper select the company SIZE (SIZE) and profitability (EPS), financial leverage (LEV), nature of the property rights and public (STATE) age
(LISTGE) as the research of control variables in this paper. In addition, annual dummy variables (YEAR) and INDUSTRY dummy variables (INDUSTRY) were added to control the annual and INDUSTRY fixed effects. The detailed variable definitions in this article shown in table 2. 
Table 2. Definition and measurement of variables.

\begin{tabular}{|c|c|c|}
\hline Variable symbol & Variable name & Variable metric \\
\hline CSR & Corporate social responsibility & Using runling global corporate social responsibility performance rating total score \\
\hline DON & Charitable donations & The proportion of the amount donated by the enterprise in the total assets of the enterprise \\
\hline POV & Poor experience & $\begin{array}{l}\text { The sum of environmental poverty experience, three-year difficulty experience and special } \\
\text { poverty experience }\end{array}$ \\
\hline POV-env & Poor environment & In the early poverty county \\
\hline POV-per & Three years of poverty & Went through a difficult period from 1959 to 19613 \\
\hline POV-spe & Experience of special poverty & Sudden natural disasters, family accidents, serious diseases and poverty caused by other factors \\
\hline EPS & Profitability & Net profit/total share capital \\
\hline LEV & Financial leverage & Asset-liability ratio $=$ total liabilities/total assets \\
\hline STATE & Property rights & State-owned property companies are assigned a value of 1 , or 0 \\
\hline LISTGE & Listed age & Listed number \\
\hline YEAR & Year & Virtual variable \\
\hline INDUSTRY & Industry & Virtual variable \\
\hline
\end{tabular}

\subsection{Research Model Construction}

In this paper, the following least squares regression model is constructed to verify the impact of poverty experience on CSR, and to verify the difference of the impact of poverty experience on CSR performance after the property right nature is distinguished.

\section{$\mathrm{CSR}=\beta_{0}+\beta_{1} \mathrm{POV}+\beta_{2} \mathrm{SIZE}+\beta_{3} \mathrm{EPS}+\beta_{4} \mathrm{LEV}+\beta_{5} \mathrm{STATE}+\beta_{6} \mathrm{LIS}$ $\mathrm{TGE}+\beta_{7}$ YEAR $+\beta_{8}$ INDUSTRY $+\varepsilon$}

\section{Empirical Test and Analysis}

\subsection{Descriptive Statistics of Variables}

Table 3 is the descriptive statistical results of the main variables studied in this paper. Can be seen from the table, the selected samples of corporate social responsibility to fulfill maximum total score is 87.95 , the minimum value is 15.12 , the median is 36.06 , the standard deviation is 12.04 , reflecting the corporate social responsibility to fulfill the overall level of China's listed companies, corporate social responsibility to fulfill different level differences, with the current our country enterprise society responsibility to perform the overall situation. From the point of view of the score of poverty experience, the minimum value is 0 , the median is 0 , the $3 / 4$ digit is 1 , and the average value is 0.44 , indicating that the proportion of the selected sample executives with early poverty experience is not particularly high, and the poverty experience level of senior executives in different enterprises is obviously different.

Table 3. Descriptive statistics of variables.

\begin{tabular}{|c|c|c|c|c|c|c|c|c|}
\hline Variable & Observations & Mean & Standard deviation & Minimum value & A quarter of double-digit & The median & Three digits & Maximum \\
\hline CSR & 1796 & 39.17 & 12.04 & 15.12 & 31.00 & 36.06 & 44.35 & 87.95 \\
\hline POV & 1796 & 0.44 & 0.58 & 0.00 & 0.00 & 0.00 & 1.00 & 3.00 \\
\hline SIZE & 1796 & 23.16 & 1.47 & 20.18 & 22.06 & 23.01 & 24.08 & 28.51 \\
\hline LEV & 1796 & 49.59 & 20.21 & 0.80 & 34.81 & 51.32 & 65.37 & 93.06 \\
\hline STATE & 1796 & 0.48 & 0.50 & 0.00 & 0.00 & 0.00 & 1.00 & 1.00 \\
\hline LISTGE & 1796 & 12.07 & 5.53 & 0.00 & 8.00 & 12.00 & 16.00 & 25.00 \\
\hline
\end{tabular}

\subsection{Regression Analysis}

Table 4 shows the sample regression results of hypothesis 1. It can be found from the regression results that the regression coefficient of poverty experience (POV) is 0.123 , which is significant at $1 \%$ level, indicating a significant positive correlation between poverty experience of senior executives and CSR performance. Senior executives with poverty experience, the more poverty experience, the higher the level of their companies to fulfill social responsibility. It indicates that the early experience of senior executives, especially the experience of poverty, what they have seen and heard and the early life experience of poverty have a positive impact on the formation of empathy in senior executives' psychology and career growth. When they become senior executives and have the ability to control resources, they will have a better understanding of the essence of fulfilling social responsibilities. Thus, hypothesis 1 is verified.

Table 4. Results of sample regression analysis.

\begin{tabular}{lll}
\hline \multirow{2}{*}{ Variable } & CSR & \\
\cline { 2 - 3 } & Coefficient & T value \\
\hline C & $-54.023 * * *$ & -11.494 \\
POV & $0.123 * * *$ & 5.909 \\
SIZE & $0.524 * * *$ & 18.908 \\
EPS & 0.003 & 0.149 \\
LEV & $-0.178 * * *$ & -6.995 \\
STATE & $0.066 * * *$ & 3.038 \\
LISTGE & $-0.099 * * *$ & -4.702 \\
YEAR & Control & \\
INDUSTRY & Control & \\
F value & $109.679 * * *$ & \\
Adj.R2 & 0.266 & \\
N & 1796 & \\
\hline
\end{tabular}

Note: *** means significant at $1 \%$ level; ** means significant at $5 \%$ level; * means significant at $10 \%$ level. 
The regression results from table 5, to distinguish the nature of property rights, non-state-owned corporate executives, poor experience (POV) coefficient is 0.157 , and under the $1 \%$ level is significantly related to the state-owned enterprise executives experience poverty (POV) coefficient is 0.101 , and under the $1 \%$ level significantly positive correlation, through two groups of executive experience poverty (POV) coefficient of contrast, the non-state-owned corporate executives, poor experience (POV), the coefficient of 0.157 is greater than the state-owned enterprise executives experience poverty (POV) coefficient is 0.101 , compared with the state-owned enterprise, The poverty experience of non-state-owned enterprise executives has a stronger correlation with the fulfillment of corporate social responsibility. Compared to executives of state-owned enterprises and non-state-owned corporate executives in childhood, no family or political background, advantages, for their early experiences, both living conditions and the career development path is more difficult, it is in the early years of hard experience cultivate their courage, saving consciousness, and the thought of helping others, be after executives, experience of poverty and suffering for others more empathy, more willing to lend a helping hand. Thus, hypothesis 2 is verified.

Table 5. Results of sample regression analysis.

\begin{tabular}{|c|c|c|c|c|}
\hline \multirow{3}{*}{ Variable } & \multicolumn{4}{|l|}{ CSR } \\
\hline & \multicolumn{2}{|l|}{ State-owned } & \multicolumn{2}{|l|}{ Non-state } \\
\hline & Coefficient & T value & Coefficient & T value \\
\hline $\mathrm{C}$ & $-64.792 * * *$ & -9.783 & $-45.758 * * *$ & -6.168 \\
\hline POV & $0.101 * * *$ & 3.319 & $0.157 * * *$ & 5.158 \\
\hline SIZE & $0.546^{* * *}$ & 15.454 & $0.467 * * *$ & 11.041 \\
\hline EPS & 0.033 & 1.086 & -0.044 & -1.312 \\
\hline LEV & $-0.127 * * *$ & -3.756 & $-0.224 * * *$ & -5.493 \\
\hline LISTGE & -0.010 & -0.355 & $-0.180 * * *$ & -5.531 \\
\hline YEAR & Control & & Control & \\
\hline INDUSTRY & Control & & Control & \\
\hline F value & $73.230 * * *$ & & $37.233 * * *$ & \\
\hline Adj.R2 & 0.296 & & 0.162 & \\
\hline $\mathrm{N}$ & 860 & & 936 & \\
\hline
\end{tabular}

Note: *** means significant at $1 \%$ level; $* *$ means significant at $5 \%$ level; * means significant at $10 \%$ level.

\subsection{Robustness Test}

\subsubsection{Change the Proxy Variable of the Explanatory Variable}

In order to test the robustness of the relationship between poverty experience and CSR fulfillment, this paper adjusted the measurement method of poverty experience as follows: Second, after the reform and opening up, China formally to the road of enriching people power, this article will "three years of hard times" that is adjusted for poverty in the period before the reform and opening up, namely: in 1978, as a poor economic times, before considering a memory of childhood time is 4 to 14 years old, was born in 1964-1974 senior executives as experienced early poverty statistics object. The specific valuation method remains unchanged. Finally, the total score of executives' poverty experience is calculated and regression verification is carried out. At the same time, in order to test the robustness of the impact of affluent environment on CSR performance, the proxy variable of affluent environment was selected from the data of China's top 100 counties released by the national bureau of statistics in 2004 for regression analysis.

Table 6. Results of robustness test.

\begin{tabular}{|c|c|c|c|c|}
\hline \multirow{3}{*}{ Variable } & \multicolumn{4}{|l|}{ CSR } \\
\hline & \multicolumn{2}{|c|}{ Poverty experiences a change in measurement } & \multicolumn{2}{|c|}{ Change in the measurement of affluence } \\
\hline & Coefficient & T value & Coefficient & T value \\
\hline $\mathrm{C}$ & $-54.439 * * *$ & -11.637 & $-58.423 * * *$ & -12.456 \\
\hline POV & $0.120 * *$ & 4.012 & & \\
\hline SIZE & $0.526^{* * *}$ & 19.117 & $0.553 * * *$ & 20.060 \\
\hline EPS & 0.004 & 0.165 & 0.009 & 0.409 \\
\hline LEV & $-0.180 * * *$ & -7.028 & $-0.183 * * *$ & -7.087 \\
\hline STATE & $0.066^{* * *}$ & 2.999 & $0.063^{* * *}$ & 2.873 \\
\hline LISTGE & $-0.105 * * *$ & -4.991 & $-0.097 * * *$ & -4.525 \\
\hline YEAR & Control & & Control & \\
\hline INDUSTRY & Control & & Control & \\
\hline F value & $110.500 * * *$ & & $102.116^{* * *}$ & \\
\hline Adj.R2 & 0.268 & & 0.253 & \\
\hline $\mathrm{N}$ & 1796 & & 1796 & \\
\hline
\end{tabular}

Note: *** means significant at $1 \%$ level; ** means significant at $5 \%$ level; * means significant at $10 \%$ level.

Table 6 shows the robustness test results: as can be seen from the regression results, the regression coefficient of 
poverty experience (POV) is 0.120 and is significant at the level of $5 \%$, indicating that after changing the measurement method, the significant positive correlation between poverty experience and CSR performance remains unchanged, which is consistent with the previous research conclusion.

\subsubsection{Change the Proxy Variable of the Explained Variable}

Be explained variable corporate social responsibility for inspection for the robustness of the findings, this paper also consider enterprise charity is closely linked with enterprises to fulfill social responsibility, at the same time in order to ensure that the charitable donations level comparability between different enterprises, with charitable donations finally accounted for the proportion of the total assets of the enterprise as alternative indicators of corporate social responsibility to fulfill, robustness inspection, as shown in table 7.

Table 7. Results of robustness test.

\begin{tabular}{lllll}
\hline \multirow{2}{*}{ Variable } & DON & & & \\
\cline { 2 - 5 } & Coefficient & T value & Coefficient & T value \\
\hline C & $0.614 * * *$ & 11.987 & $0.534^{* * *}$ & 10.386 \\
POV & $0.262 * * *$ & 6.181 & & \\
STR-05 & & & 0.009 & 0.227 \\
SIZE & 0.038 & 0.698 & $0.136 * *$ & 2.506 \\
EPS & $0.169 * * *$ & 3.987 & $0.217^{* * *}$ & 4.984 \\
LEV & $-0.124 * *$ & -2.503 & $-0.152^{* * *}$ & -2.973 \\
STATE & $-0.288^{* * *}$ & -6.551 & $-0.333^{* * *}$ & -7.379 \\
LISTGE & $-0.150^{* * *}$ & -3.573 & $-0.170^{* * *}$ & -3.914 \\
YEAR & Control & & Control & \\
INDUSTRY & Control & & Control & \\
F value & $29.288^{* * *}$ & & $21.283^{* * *}$ & \\
Adj.R2 & 0.259 & & 0.200 & \\
N & 487 & & 487 & \\
\hline
\end{tabular}

Note: $* * *$ means significant at $1 \%$ level; ** means significant at $5 \%$ level; * means significant at $10 \%$ level.

According to the regression results, after changing the measurement index of corporate social responsibility, the regression coefficient of poverty experience (POV) is 0.262 , and it is significantly positively correlated with corporate charitable donation (DON) at the 1\% level, that is, the higher the CSR performance level of executives with poverty experience. The regression coefficient of str-05 was 0.009 , but it was not significant, indicating that the early rich environment experience of senior executives did not significantly improve the level of CSR performance, which verified the accuracy of the conclusions of this paper.

\section{Conclusion}

This paper took the listed companies in Shanghai and shenzhen from 2012 to 2015 as the research object, studied the impact of senior executives' poverty experience on CSR performance, and analyzed the impact difference of senior executives' poverty experience on CSR performance under different property rights. The research findings of this paper are as follows: (1) there is a significant positive correlation between executives' poverty experience and CSR performance. Senior executives who have experienced poverty in the early stage have relatively high level of social responsibility performance, which indicates that the experience of poverty in the early stage has a great impact on senior executives' memory of poverty and makes them more compassionate. When they have the ability to control resources and make decisions, they are more willing to give back to the society. (2) the poverty experience of senior executives of non-state-owned enterprises has a stronger influence on the fulfillment of corporate social responsibility. Different from the life experience of executives in state-owned enterprises, the early growth environment of non-state-owned enterprise executives is more harsh and the career development trajectory is more difficult, which makes non-state-owned enterprise executives understand the essence of helping others better.

The conclusion of this paper has important theoretical and practical significance. (1) research on the impact of executives' poverty experience on corporate social responsibility is rare in existing research literature. (2) through the establishment of quantitative indicators and models of poverty experience, and empirical analysis of the impact of CSR performance mechanism, this paper provides new ideas and measurement methods for relevant research reference; (3) through in this paper, the study found that in the performance of corporate social responsibility motivation, in addition to the economic development, institutional constraints and the external pressure, executives from poverty through formation of the moral and emotional cognition also have important influence to corporate social responsibility to fulfill, the discovery of this conclusion can help the government and enterprises in the future the social responsibility of the transaction management in a targeted work, to enhance the level of our country enterprise society responsibility to perform a positive guiding significance.

\section{References}

[1] Bert Scholtens. A Note on the Interaction Between Corporate Social Responsibility and Financial Performance [J]. Ecological Economics, 2008 (68): 46-55.

[2] Zyglidopoulos, Georgiadis. Does Media Attention Drive Corporate Social Responsibility? [J]. Journal of Business Research, 2012, 65 (11): 1622-1627.

[3] Porter, M. E, Kramer, M. R. Strategy and Society: The Link between Competitive Advantage and Corporate Social Responsibility [J]. Harvard Business Review, 2006 (12): 36-37.

[4] Healy, P. M. The Effect of Bonus Schemes on Accounting Decisions [J]. Journal of Accounting and Economics, 1985, 7 (1): $18-21$.

[5] Batson J., J. K. Slingsby. Empathic Joy and the Empathy Altruism Hypothesis [J]. Journal of Personality and Social Psychology, 1991, 61 (4): 13-26.

[6] Benmelech, E., and C. Frydman. Military CEOs [J]. Journal of Financial Economics, 2015 (117): 43-59. 
[7] Moon, J., and X. Shen. CSR in China Research: Salience, Focus and Nature [J]. Journal of Business Ethics, 2010, 94 (4): 613-629.

[8] Hahn, A., and B. Gawronski. Implicit Social Cognition [J]. International Encyclopedia of the Social and Behavioral Sciences, 2015 (17): 714-720.

[9] Holman, E, A., Silver, R, C. Getting Stuck in the Past: Temporal orientation and coping with trauma [J]. Journal of personality and Social Psychology, 1998, 74 (5): 1146-1163.

[10] Malmendier, U., Tate. Overconfidence and Early life Experiences: The Effect of Managerial Traits on Corporate Financial Policies [J]. Journal of Finance, 2011 (66): $1687-1733$

[11] [Hambrick, D. C., Mason, P. A. Upper Echelons: The Organization As a Reflection of its Top Managers [J]. Academy of Management Review, 1984, 9 (2): 193-206.

[12] Graham, J., Harvey, and M. Puri. Capital Allocation and Delegation of Decision making Authority within Firms [J]. Journal of Financial Economics, 2015 (115): 449-470.

[13] Steven F. Cahan, Chen Chen, Nhut H. Nguyen. Corporte Social Responsibility and Media Coverage [J]. Journal of Banking and Finance, 2015 (59): 19-27.
[14] Benson. What Determines Success? Examining The Human, Financial and Social Capital of Jamaican Micro-entrepreneurs [J]. Journal of Business Venturing, 1998 (13): 371-394.

[15] Shan Liwei, Gan Li, Zheng Tao. Corporate Contributions and Economic Motivation: An Empirical Study of Chinese Listed Companies' Contributions after the Wenchuan Earthquake [J]. Economic Research, 2008 (11): 51-55.

[16] Xu Nianxing, Li Zhe. Executive Poverty Experience and Corporate Charitable Donation [J]. Economic Research, 2016 (12): 133-140

[17] Zhang Zhixue, Zhang Jianjun, Liang Shuping. The Effectiveness of Enterprise System and Corporate Culture: The View of Organizational Control [J]. Economic Sciences, 2006 (1): $117-128$.

[18] Cui Xiumei, Liu Jing. The Process of Marketization, the Nature of Ultimate Controller and Corporate Social Responsibility__Evidence from Shanghai Listed Companies [J]. Soft Science, 2009, 23 (1): 30-37.

[19] Liu Fengjun, Li Jingqiang, Li Hui. An Empirical Study on the Relationship between Corporate Social Responsibility and Brand Influence [J]. China Soft Science, 2012 (1): 116-121. 